\title{
PENERAPAN PENDEKATAN CONTEXTUAL TEACHING AND LEARNING (CTL) UNTUK MENINGKATKAN HASIL BELAJAR SISWA PADA MATERI PERBANDINGAN DI KELAS VII SMP NEGERI 22 PALU
}

\author{
Nurfidiya ${ }^{1)}$,Dasa Ismaimuza ${ }^{2)}$,Ibnu Hadjar ${ }^{3)}$ \\ nurfidiyadidi@gmail.com ${ }^{1}$,dasaismaimuza@gmail.org.uk ${ }^{2}$, ,ibnuhadjar67@gmail.com ${ }^{3}$
}

\begin{abstract}
Abstrak: Penelitian ini bertujuan untuk mendeskripsikan tentang penerapan pendekatan Contextual Teaching and Learning yang dapat meningkatkan hasil belajar siswa pada materi perbandingan di kelas VII SMP Negeri 22 Palu. Penelitian ini adalah Penelitian Tindakan Kelas (PTK) yang mengacu pada desain penelitian Kemmis dan Mc. Taggart, yakni perencanaan, tindakan, observasi, dan refleksi. Penelitian ini dilaksanakan dalam dua siklus. Subjek penelitian ini adalah siswa kelas VII SMP Negeri 22 Palu yang terdaftar pada tahun ajaran 2017/2018. Jumlah subjek penelitian ini adalah 27 siswa dan terpilih 3 siswa sebagai informan. Pada penelitian yang telah dilaksanakan, diperoleh bahwa dari hasil observasi guru dan siswa pada siklus I pada kategori baik dengan persentase aktivitas guru 79,41\% dan aktivitas siswa 73,53\% sedangkan hasil observasi guru dan siswa pada siklus II pada kategori sangat baik dengan persentase aktivitas guru 94,12 \% dan aktivitas siswa 85,29 \% sehingga hasil belajar siswa Kelas VII SMP Negeri 22 Palu mengalami peningkatan. Berdasarkan hasil tersebut, dapat disimpulkan bahwa penerapan Pendekatan CTL dapat meningkatkan hasil belajar siswa pada materi perbandingan di SMP Negeri 22 Palu dengan melibatkan 7 komponen utama, yaitu : (1) constructivism (konstruktivisme), (2) questioning (bertanya), (3) inquiry (menemukan), (4) learning community (masyarakat belajar), (5) modelling (pemodelan), (6) reflection (refleksi), dan (7) authentic assessment (penilaian autentik).
\end{abstract}

Kata kunci: contextual teaching and learning, hasil belajar, perbandingan

\begin{abstract}
This research was aimed to describe about the application of Contextual Teaching and Learning in order to improve Learning outcomesin proportion of grade VII students' at SMP Negeri 22 Palu. It was a class action research referred from Kemmis and Mc.Taggart's design of research which explained to do actions of planning, observation, and reflection. It applied into two cycles. Subject of this research was grade VII students' at SMP Negeri 22 Palu registered in 2017/2018 years. Total subjects in the class were 27 students and 3 of them were chosen as informants.In the research that has been carried out, it was found that from the results of teacher and student observations in the first cycle in the good category with the percentage of teacher activity 79,41 \% and student activities $73.53 \%$ while the results of teacher and student observations in the second cycle in the excellent category with a percentage Teacher activity $94.12 \%$ and student activity $85.29 \%$ so that the learning outcomes of Class VII students of SMP Negeri 22 Palu have increased.Based on these results, it can be concluded that the application of the CTL Approach can improve student learning outcomes in comparison material in SMP Negeri 22 Palu involving 7 main components, namely: (1) constructivism (constructivism), (2) questioning (asking), (3) inquiry (inquiry), (4) learning community (learning community), (5) modeling (modeling), (6) reflection (reflection), and (7) authentic assessment.
\end{abstract}

Keywords: contextual teaching and learning, learning outcomes, proportion..

Seiring dengan perkembangan teknologi yang semakin pesat maka dibutuhkan juga sumber daya manusia yang berkualitas, sumber daya manusia yang berkualitas sangat diperlukan untuk menghadapi tantangan dunia pada era globalisasi yang penuh dengan persaingan. Ada kemungkinan bila sebuah negara yang mempunyai kualitas sumber daya manusia rendah akan tertinggal jauh dengan negara-negara lain. Rendahnya kualitas sumber 
daya manusia dapat disebabkan oleh rendahnya kualitas pendidikan. Indonesia merupakan salah satu negara yang menghendaki sumber daya manusia yang tinggi.

Berbicara tentang mutu pendidikan, tentunya tidak lepas dari kegiatan pembelajaran berbagai mata pelajaran di kelas. Salah satunya mata pelajaran matematika, dimana matematika merupakan mata pelajaran yang potensial untuk diajarkan diseluruh jenjang pendidikan mulai dari sekolah dasar untuk membekali siswa dengan kemampuan berpikir logis, kritis dan sistematis serta kemampuan bekerjasama sehingga tercipta kualitas sumber daya manusia sesuai dengan tujuan pendidikan nasional. Hal ini sesuai dengan tujuan pembelajaran matematika adalah membentuk kemampuan bernalar pada diri siswa yang tercermin melalui kemampuan berpikir logis, kritis, sistematis, dan memiliki sifat objektif, jujur, disiplin dalam memecahkan suatu permasalahan dalam bidang matematika maupun dalam kehidupan sehari-hari (Depdiknas, 2006).

Prinsip dan konsep matematika banyak dijumpai dalam kehidupan sehari-hari dan penggunaannya dalam mengungkap fenomena yang terjadi di sekitar manusia. Karena manfaat itu, siswa seharusnya memiliki dasar-dasar pengetahuan mengenai pengetahuan fakta, konsep, prinsip maupun pengetahuan prosedur matematika. Proses pembelajaran matematika di sekolah, selalu melibatkan keempat komponen tersebut. Sehingga, penguasaan terhadap hal tersebut menjadi tuntutan yang tidak boleh dilalaikan oleh guru dalam memberikan pemahaman dan pengetahuan kepada para siswa. Namun, hal yang terjadi di lapangan banyak siswa yang belum memiliki pengetahuan yang benar, baik mengenai pengetahuan fakta, konsep, prinsip, dan prosedur matematika.

Kondisi tersebut sangat berpengaruh terhadap hasil belajar siswa. Beberapa penyebab rendahnya hasil belajar siswa pada mata pelajaran matematika adalah objek-objek matematika yang bersifat abstrak dan kurangnya pemahaman siswa terhadap pengetahuan dasar dalam matematika. Akibatnya pada saat siswa menjawab soal-soal matematika, banyak ditemukan kesalahan prosedur.

Berdasarkan hasil wawancara guru mata pelajaran matematika di SMP Negeri 22 Palu, pada tanggal 25 Maret 2017, diperoleh informasi bahwa masih banyak siswa yang belum bisa menyelesaikan soal perbandingan senilai perbandingan berbalik nilai karena siswa belum memahami dengan baik konsep perbandingan.

Masalah tersebut dikarenakan masih kurangnya perhatian siswa kepada guru saat proses pembelajaran, mudah terpancing untuk bermain didalam kelas, mudah lupa dengan materi yang telah dijelaskan dan tidak memiliki sikap berani bertanya. Kondisi seperti ini mengganggu proses belajar dan berakibat rendahnya pemahaman siswa terhadap materi yang diajarkan dan berujung pada rendahnya hasil belajar siswa pada materi perbandingan. Sebagaimana jawaban siswa pada tes identifikasi berikut.
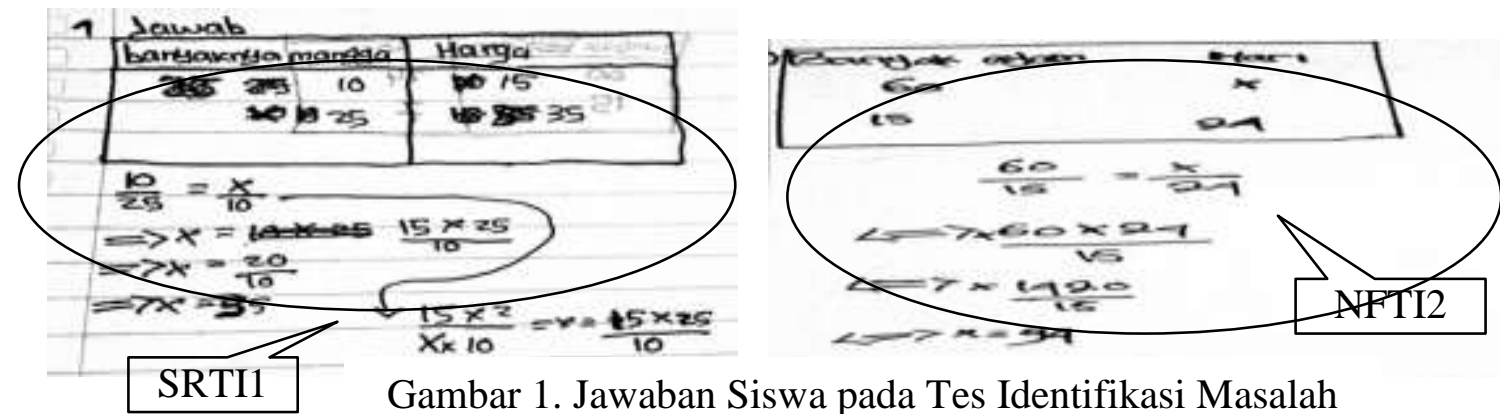

Gambar 1. Jawaban Siswa pada Tes Identifikasi Masalah 
Gambar 1 menunjukkan bahwa siswa SR belum dapat menuliskan apa yang diketahui dan apa yang ditanyakan dengan lengkap (SRTI1), belum dapat menuliskan model matematika dengan benar dan belum dapat menentukan permisalan soal sehingga keliru dalam menyelesaikan soal perbandingan senilai yang diberikan (SRTI1). Pada soal no 2 siswa NF belum mengerti maksud soal, belum dapat menuliskan apa yang diketahui dan apa yang ditanyakan dengan lengkap (NFTI2), dan dalam menuliskan model matematika siswa tersebut menulis permisalan yang terbalik sehingga keliru dalam menyelesaikan soal perbandingan berbalik yang diberikan (NFTI2).

Berdasarkan jawaban hasil tes identifikasi maka peneliti berasumsi bahwa masalahmasalah yang terdapat pada tes identifikasi tersebut terjadi pada siswa SMP Negeri 22 Palu dan kesalahan-kesalahan yang dilakukan siswa dikarenakan siswa tidak tahu konsep terkait materi perbandingan akibatnya masih keliru menentukan dan menyelesaikan soal perbandingan senilai dan perbandingan berbalik nilai.

Berdasarkan penjelasan di atas maka peneliti menerapkan suatu pembelajaran yang cocok untuk mengatasi masalah di atas. Pendekatan yang cocok yakni Pendekatan CTL (Contextual Teaching and Learning) yang merupakan konsep yang mengaitkan materi yang dipelajari dengan realitas kehidupan nyata, sehingga semua materi yang disampaikan kepada siswa dapat menyentuh realitas kehidupan sehari-hari dengan demikian pembelajaran akan lebih bermakna karena siswa mengalami apa yang dipelajarinya, tidak sekedar menghafal.

Dari penjelasan di atas Pendekatan CTL (Contextual Teaching and Learning) dapat mendorong siswa membuat hubungan antara pengetahuan yang dimilikinya dengan penerapannya dalam kehidupan mereka sebagai anggota keluarga dan masyarakat. Proses pembelajaran akan berlangsung alamiah dalam bentuk kegiatan siswa bekerja dan mengalami, tidak hanya mentransfer pengetahuan dari guru ke siswa.

Menurut Suyadi (Jurdin, 2015) keunggulan pembelajaran kontekstual adalah : (1) pembelajaran kontekstual dapat mendorong siswa menemukan hubungan antara materi yang dipelajari dengan situasi kehidupan nyata. Artinya siswa secara tidak langsung dituntut untuk menangkap hubungan antara pengalaman belajar di sekolah dengan kehidupan nyata di lingkungan masyarakat, sehingga mampu menggali, berdiskusi, berpikir kritis, dan memecahkan masalah nyata yang dihadapi dengan cara bersama-sama, (2) pembelajaran kontekstual mampu mendorong siswa untuk menerapkan hasil belajarnya dalam kehidupan nyata. Artinya siswa tidak hanya diharapkan dapat memahami materi yang dipelajarinya, tetapi bagaimana materi pelajaran itu dapat mewarnai perilaku/tingkah laku dalam kehidupan sehari-hari, dan (3) pembelajaran kontekstual menekankan pada proses keterlibatan siswa untuk menemukan materi. Artinya, proses belajar diorientasikan pada proses pengalaman tidak langsung. Proses belajar dalam CTL tidak mengharapkan siswa hanya menerima materi pelajaran, melainkan dengan cara proses mencari dan menemukan sendiri materi pelajaran.

Pendekatan kontekstual harus menekankan hal-hal sebagai berikut: (1) problem based learning (belajar berbasis masalah), (2) authentic instruction (pengajaran autentik), (3) inquiry based learning (belajar berbasis inquiri), (4) project based learning (belajar berbasis proyek atau tugas), (5) work based learning (belajar berbasis kerja), (6) service learning (belajar berbasis jasa layanan), (7) cooperative learning (belajar kooperatif) (Hadjar, 2014).

Berdasarkan uraian di atas, maka peneliti tertarik untuk melakukan penelitian dengan judul "Penerapan Pendekatan CTL untuk meningkatkan hasil belajar siswa pada materi perbandingan di Kelas VII SMP Negeri 22 Palu".

Rumusan masalah pada penelitian ini adalah "Bagaimana penerapan pendekatan CTL yang dapat meningkatkan hasil belajar siswa pada materi perbandingan di kelas VII SMP Negeri 22Palu?" 
Nurfidiya, Dasa Ismaimuza, dan Ibnu Hadjar, Penerapan Pendekatan ... 87

\section{METODE PENELITIAN}

Penelitian ini dilakukan di SMP Negeri 22 Palu yang beralamat di Jalan Bora Indah, Kelurahan Pantoloan Boya, Kecamatan Tawaeli, Kota Palu, Provinsi Sulawesi Tengah. Subjek penelitian ini adalah seluruh siswa di kelas VII SMP Negeri 22 Palu yang terdaftar pada tahun ajaran 2017/2018 dengan jumlah siswa 27 orang, terdiri dari 16 siswa laki-laki dan 11 siswa perempuan. Dari subjek penelitian, dipilih 3 siswa sebagai informan dengan karakteristik informan yaitu DV berkemampuan tinggi, DN berkemampuan sedang dan AI berkemampuan rendah. Jenis penelitian ini adalah penelitian tindakan kelas. Penelitian ini dilaksanakan dalam dua siklus. Masing-masing siklus terdiri atas empat tahapan yaitu: 1) perencanaan; 2) pelaksanaan tindakan; 3) observasi dan 4) refleksi.

Teknik pengumpulan data yang digunakan yaitu teknik observasi, wawancara, pencatatan lapangandan tes. Data yang diperoleh dianalisis dengan mengacu pada model Miles dan Huberman (Sugiyono, 2014) yaitu data condensation (kondensasi data), (2) data display (penyajian data), (3) conclution drawing/verification (kesimpulan/verifikasi).

Kriteria keberhasilan tindakan dalam penelitian ini ditentukan berdasarkan: (1) Proses pembelajaran berjalan dengan baik. (2) Hasil belajar siswa pada materi perbandingan meningkat. Siswa dikatakan tuntas jika memperoleh nilai lebih dari atau sama dengan 75 dan dengan ketuntasan belajar klasikal lebih dari atau sama dengan $70 \%$ yang telah ditetapkan di SMP Negeri 22 Palu.

\section{HASIL PENELITIAN}

Hasil penelitian ini terbagi dalam dua bagian, yaitu (1) hasil pratindakan, dan (2) hasil pelaksanaan tindakan. Kegiatan pratindakan dilakukan peneliti dengan memberikan tes awal kepada siswa-siswi kelas VII. Hal ini dimaksudkan untuk mengetahui tingkat pengetahuan prasyarat siswa sebelum memulai materi penelitian tentang perbandingan. Hasil tes awal ini jugadijadikan sebagai pedoman untuk menentukan informan dan pengetahuan masing-masing siswa. Hasil analisis tes awal menunjukkan bahwa kesalahan yang sering dilakukan siswa adalah kesalahan dalam menentukan pecahan perbandingan senilai dan berbalik nilai, menentukan nilai yang akan dicari serta operasi perkalian dan pembagiannya. Dari hasil tersebut terlihat bahwa skor tertinggi yang diperoleh siswa adalah 80, skor yang terendah yang dicapai siswa adalah 20 . Siswa yang memperoleh nilai yang memenuhi standar ketuntasan adalah 6 orang, sedangkan yang tidak memenuhi standar ketuntasan berjumlah 21 orang. Ini berarti bahwa ada 21 orang siswa yang bermasalah di dalam kelas.

Adapun pelaksanaan pembelajaran materi perbandingan senilai dan berbalik nilai dilakukan peneliti dengan menerapkan pendekatan CTL yang disesuaikan pada setiap kegiatan pendahuluan, kegiatan inti dan kegiatan penutup. Adapun langkah-langkah pendekatan CTL menurut Muslich (Harmawati, 2016) pendekatan CTL melibatkan 7 komponen utama, yaitu : (1) constructivism (konstruktivisme), (2) questioning (bertanya), (3) inquiry (menemukan), (4) learning community (masyarakat belajar), (5) modelling (pemodelan), (6) reflection (refleksi), (7) authentic assessment (penilaian autentik).

Pelaksanaan tindakan pada setiap siklus dilakukan dengan tiga kegiatan yaitu kegiatan pendahuluan, kegiatan inti dan kegiatan penutup. Adapun langkah-langkah pelaksanaan pembelajaran materi perbandingan senilai dengan pendekatan CTL pada langkah kegiatan pendahuluan yaitu peneliti melaksanakan absensi, menyampaikan tujuan pembelajaran dan memotivasi siswa serta memberikan apersepsi mengenai materi yang akan dipelajari, setelah itu peneliti mendampingi siswa mengkonstruksi pengetahuan mereka melalui interaksi mereka dengan objek, fenomena, pengalaman, dan lingkungan mereka serta guru memberikan stimulis 
agar siswa mengungkapkan apa yang ada dalam pikiran siswa. Pada kegiatan ini peneliti menerapkan komponen CTL yang muncul Konstruktivisme, pada langkah kegiatan Inti peneliti menyajikan suatu masalah yang ada dikehidupan sehari-hari yang berkaitan dengan materi yang diajarkan dan peneliti mengarahkan siswa untuk dapat menemukan pemecahan masalah yang diberikan. Pada kegiatan ini peneliti menerapkan komponen CTL menemukan, kemudian peneliti mengorganisasikan siswa kedalam kelompok-kelompok belajar yang heterogen dan peneliti membagikan LKPD serta model yang digunakan sebagai contoh pembelajaran. Pada kegiatan ini peneliti menerapkan komponen CTL Masyarakat Belajar, selanjutnya guru meminta perwakilan setiap kelompok untuk menyajikan hasil didkusi kelompoknya dengan memperagakan kembali cara siswa menemukan. Pada kegiatan ini peneliti menerapkan komponen CTL Pemodelan, setelah itu peneliti menggali pemahaman siswa dengan cara tanya jawab untuk mengetahui tingkat pemahaman siswa mengenai materi yang dipelajari. Pada kegiatan ini peneliti menerapkan komponen CTL bertanya, kemudian peneliti memonitoring kerja siswa, menjelaskan kepada siswa agar dapat bekerja sama, serta membimbing siswa jika ada yang belum dipahami dan peneliti mengumpulkan LKPD hasil diskusi siswa dalam kelompok. Pada kegiatan ini peneliti menerapkan komponen CTL penilaian autentik, langkah terakhir pada kegiatan ini yaitu peneliti memberikan penghargaan kepada kelompok terbaik, dan pada langkah kegiatan Penutup peneliti membimbing siswa untuk membuat kesimpulan sesuai dengan tujuan pembelajaran yang telah ditentukan dan peneliti memberikan refleksi terhadap kegiatan pembelajaran yang telah dilakukan. Pada langkah ini peneliti menerapkan komponen CTL refleksi.

Kegiatan pendahuluan dilakukan peneliti dengan melaksanakan absensi, menyampaikan tujuan pembelajaran dan memotivasi siswa serta memberikan apersepsi mengenai materi yang akan dipelajari agar siswa mengetahui tujuan pembelajaran dan gambaran materi yang akan dipelajari sehingga siswa tertarik untuk belajar tentang materi yang akan diajarkan. selanjutnya peneliti mendampingi siswa mengkonstruksi pengetahuan mereka melalui interaksi mereka dengan objek, fenomena, pengalaman, dan lingkungan mereka serta peneliti memberikan stimulis agar siswa mengungkapkan apa yang ada dalam pikiran siswa. Pada kegiatan ini peneliti menerapkan komponen CTL yang muncul Konstruktivisme.

Kemudian kegiatan inti dilakukan peneliti dengan menyajikan suatu masalah yang ada dikehidupan sehari-hari yang berkaitan dengan materi yang diajarkan dan peneliti mengarahkan siswa untuk dapat menemukan pemecahan masalah yang diberikan. Pada kegiatan ini peneliti menerapkan komponen CTL menemukan, langkah selanjutnya peneliti mengorganisasikan siswa kedalam kelompok-kelompok belajar yang heterogen dan peneliti membagikan LKPD serta model yang digunakan sebagai contoh pembelajaran. Pada kegiatan ini peneliti menerapkan komponen CTL Masyarakat Belajar, kemudian peneliti meminta perwakilan setiap kelompok untuk menyajikan hasil didkusi kelompoknya dengan memperagakan kembali cara siswa menemukan. Pada kegiatan ini peneliti menerapkan komponen CTL Pemodelan, setelah itu yang dilakukan peneliti yaitu dengan menggali pemahaman siswa dengan cara tanya jawab untuk mengetahui tingkat pemahaman siswa mengenai materi yang dipelajari. Pada kegiatan ini peneliti menerapkan komponen CTL bertanya, selanjutnya peneliti memonitoring kerja siswa, menjelaskan kepada siswa agar dapat bekerja sama, serta membimbing siswa jika ada yang belum dipahami dan peneliti mengumpulkan LKPD hasil diskusi siswa dalam kelompok. Pada kegiatan ini peneliti menerapkan komponen CTL penilaian autentik, dan langkah terakhir yaitu peneliti memberikan penghargaan kepada kelompok terbaik.

Kegiatan penutup dilakukan peneliti dengan membimbing siswa untuk membuat kesimpulan sesuai dengan tujuan pembelajaran yang telah ditentukan dan peneliti memberikan 
refleksi terhadap kegiatan pembelajaran yang telah dilakukan. Pada kegiatan ini peneliti menerapkan komponen CTL refleksi. Setelah melaksanakan pembelajaran, peneliti memberikan tes akhir tindakan untuk mengetahui perkembangan pemahaman siswa. Jumlah siswa yang mengikuti tes pada siklus I berjumlah 27 siswa.Tes akhir siklus I terdiri dari 3 soal. Salah satu soalnya adalahPerbandingan banyaknya hasil panen jagung pak Agus dan pak Bambang adalah $4: 5$. Jika jumlah hasil panen jagung keduanya adalah $90 \mathrm{~kg}$. tentukan masing-masing jumlah jagungpak Agus dan pak Bambang !

Hasil yang diperoleh dari tes akhir siklus I menunjukkan bahwa pada umumnya siswa dapat menyelesaikan soal yang diberikan. Namun masih ditemukan beberapa siswa yang melakukan kesalahan dalam menyelesaikan soal pada saat menentukan nilai perbandingan senilai.

Jawaban siswa (DN) dan (AI) terhadap soal tes akhir tindakan siklus I disajikan dalam Gambar 2.
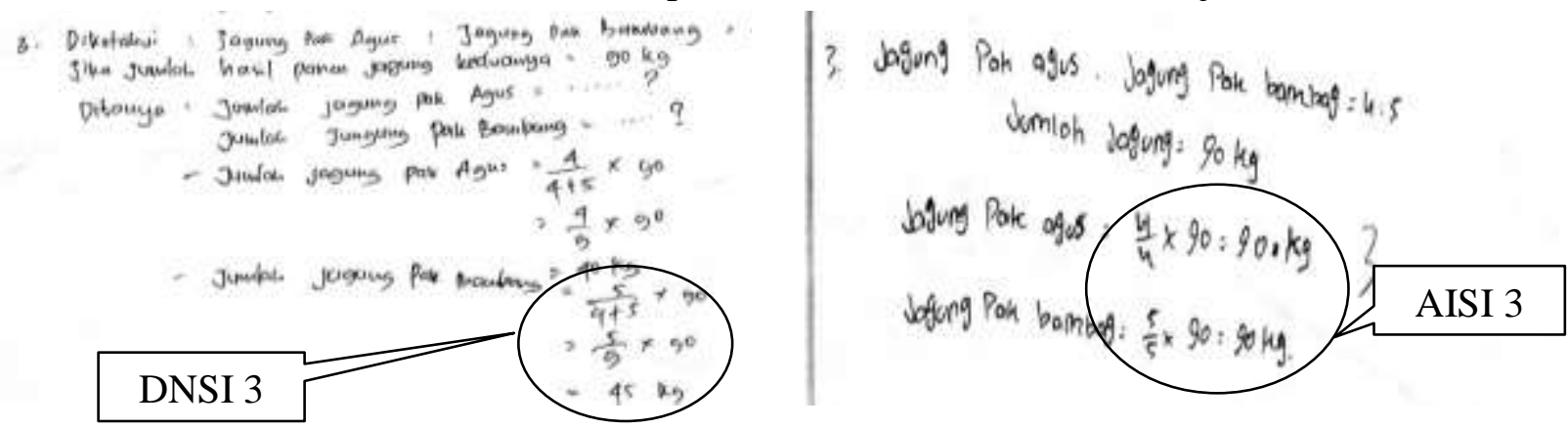

Gambar 2. Jawaban Siswa pada Soal Tes Akhir Tindakan Siklus I

Gambar 2 menunjukkan bahwa siswa DN dan AI melakukan kesalahan dengan tidak memperhatikan petunjuk soal yang diberikan. Siswa DN menjawab $\frac{4}{4+5}$ (DNSI3). Seharusnya siswa DN menuliskan $\frac{4}{5+4}$ karena yang ditanyakan adalah jumlah jagung pak Bambang. Kesalahan lainnya dilakukan oleh siswa AI dengan menuliskan $\frac{4}{4}$ untuk mencari jumlah jagung pak Agus dan $\frac{5}{5}$ untuk mencari jumlah jagung pak Bambang (AISI 3) seharusnya hal tersebut tidak perlu dilakukan, sehingga hasil yang didapatkan keliru.

Peneliti melakukan wawancara dengansiswa $\mathrm{DN}$ dan $\mathrm{AI}$, dalam rangka memperoleh informasi lebih lanjut tentang kesalahan siswa DN dan AI. Berikut kutipan wawancara peneliti dengan siswa DN.

DN SI $11 \mathrm{P}$ : coba lihat jawabanmu no.3.! apanya yang salah?

DN SI $12 \mathrm{~S}$ : Ai iya ka saya tulis $\frac{5}{4+5}$ bukan $\frac{5}{5+4}$ ka bagimana saya buru-buru mau cepat selesai. Jadi sudah salah mengalikan saya ka baru tidak lagi saya tulis kesimpulannya.

DN SI 13 P : nanti kalau mengerjakan soal jangan buru-buru mau cepat selesai diperiksa baik-baik dulu baru dikumpul.

DN SI $14 \mathrm{~S}$ : ok kak.

Berikut kutipan wawancara dengan AI:

AI SI 18 P : kalau no.3 kenapa jawabannya $\frac{4}{4}$ dan $\frac{5}{5}$ ?

AI SI $19 \mathrm{~S}$ : Bagaimana soal nomor 1 dan 2 cuma satu pembaginya jadi nomor 3 saya tulis juga cuma 1 pembaginya kak 
AI SI $20 \mathrm{P}$ : Nah, kalau nomor 3 jawabannya harus seharusnya jumlah jagung pak Agus $\frac{4}{4+5} \mathrm{x}$ $90 \mathrm{~kg}=\frac{4}{9} \times 90 \mathrm{~kg}=40 \mathrm{~kg}$ dan jumlah jagung pak Bambang $\frac{5}{5+4} \times 90 \mathrm{~kg}=\frac{5}{9} \times 90$ $\mathrm{kg}=50 \mathrm{~kg}$. mengerti?

AI SI $21 \mathrm{~S}$ : Oh Iye kak.

AI SI 22 P : Kenapa kalau jumlah jagung pak Bambang ditulis $\frac{5}{5+4}$ bukan $\frac{4}{4+5}$ ?

AI SI $23 \mathrm{~S}$ : Karena yang ditanyakan jumlah jagung pak Bambang jadi $\frac{5}{5+4}$ bukan $\frac{4}{4+5}$

AI SI $24 \mathrm{P}$ : Iya, bagus . Kamu harus belajar lebih giat lagi ya !

AI SI $25 \mathrm{~S}$ : Iye kak.

Berdasarkan hasil wawancara dengan siswa DN diperoleh informasi bahwa siswa DN kurang teliti dalam menjawab soal dengan mengabaikan perintah soal yang telah ada, selain itu DN juga belum mamahami konsep untuk menentukan nilai dari perbandingan senilai. Sedangkan siswa AI juga masih belum dapat menyelesaikan soal yang diberikan dengan benar, siswa AI juga mangabaikan perintah soal yang diberikan dan kesalahan tersebut juga dikarenakan siswa hanya mengikuti jawaban soal sebelumnya. Saat dibimbing oleh peneliti siswa AI dapat menjawab dengan benar.

Berdasarkan hasil tes akhir tindakan siklus I, diperoleh informasi bahwa dari 27 siswa yang mengikuti tes akhir tindakan,16 siswa yang tuntas dan 11 siswa lainnya tidak tuntas karena belum mencapai kriteria ketuntasan belajar. Adapun persentase ketuntasan belajar klasikal yang dicapai pada siklus I sebesar $59.25 \%$.

Tes akhir pada siklus II terdiri dari 3nomor soal. Berdasarkan jawaban siswa pada soal menentukan perbandingan berbalik nilai, berikut jawaban siswa (DN) terhadap soal tes akhir tindakan siklus II disajikan dalam Gambar 3.

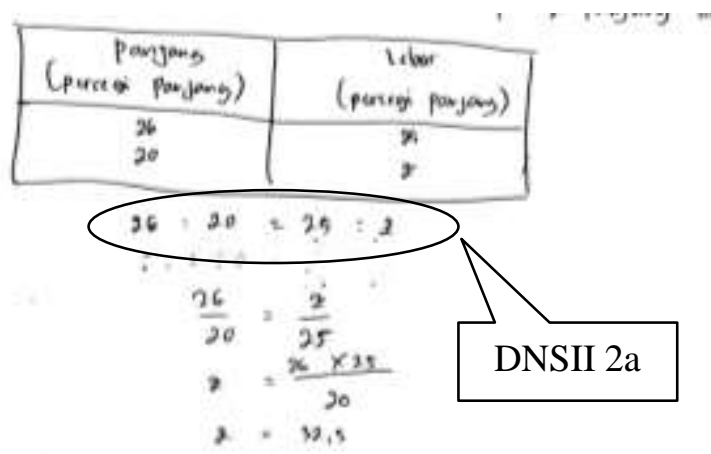

(i)

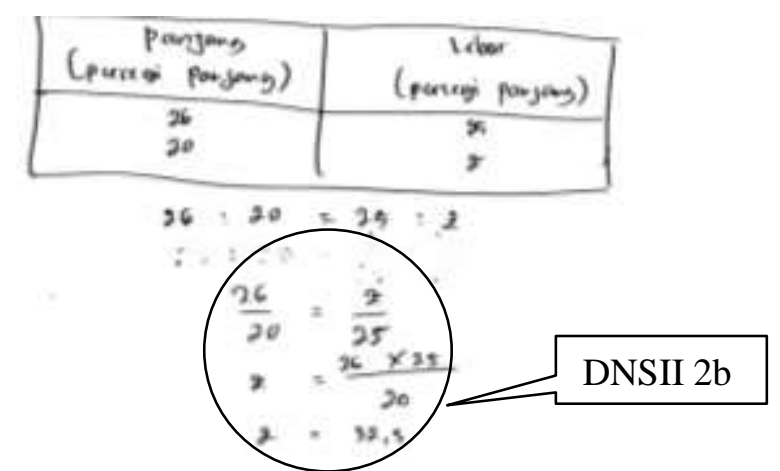

(ii)

Gambar 3 Jawaban Siswa DN pada Soal Tes Akhir Tindakan Siklus II

Gambar 3 menunjukkan bahwa siswa DN telah mampu menuliskan pemisalan dengan benar namun belum memahami soal dengan baik sehingga perbandingannya salah. Siswa DN juga masih mengerjakan soal dengan konsep perbandingan senilai sehingga jawaban masih keliru. Dikarenakan siswa DN terburu-buru dalam mengerjakan soal sehinggai jawaban yang didapatkan keliru.

Hasil tes akhir tindakan siklus II menunjukkan bahwa pada umumnya siswa dapat menyelesaikan dengan langkah-langkah yang benar namun terkadang kurang teliti. Dalam rangka memperoleh informasi lebih lanjut tentang kesalahan siswa DN, peneliti melakukan wawancara dengan siswa DN. Berikut petikan wawancara peneliti dengan siswa DN.

DN S2 25 P : silahkan jelaskan hasil pekerjaanmu di nomor 3. 
DN S2 $26 \mathrm{~S}$ : apanya yang salah ka? saya lihat sudah betul ini ka

DN S2 27 P : Iya pemisalannya sudah betul tapi konsep yang dipakai salah dek, yang kamu pakai itu adalah konsep perbandingan senilai bukan perbandingan berbalik nilai

DN S2 28 S : Oh, iya kurang teliti saya kak bagaimana buru-buru saya mengerjakan kak jadi tidak lagi saya cek ulang pekerjaanku

DN S2 $29 \mathrm{P}$ : Oh iya, coba kamu jelaskan ulang bagaiaman jawabannya!

DN S2 $30 \mathrm{~S}$ : oh berarti diketahui panjang persegi panjangnya adalah $26 \mathrm{~cm}$ dan $25 \mathrm{~cm}$ dan lebarnya $20 \mathrm{~cm}$ dan dimisalkan panjang yang dicari adalah $\mathrm{z}$ sehingga $\frac{26}{25}=\frac{\mathrm{z}}{20}$ jadi $\mathrm{z}=\frac{26 \times 20}{25}$ hasilnya $\mathrm{z}=20,8 \mathrm{~cm}$.

DN S2 $31 \mathrm{P}$ : iya,baik. kalau mengerjakan soal lain jangan buru-buru lagi ee, dicek dulu baru dikumpulkan

DN S2 32 S : Ok kak.

Berdasarkan hasil wawancara siklus II diperoleh informasi bahwa siswa AI sudah memahami dalam menentukan perbandingan berbalik nilai namun masih terburu-buru dalam mengerjakan soal sehingga masihmenggunakan konsep perbandingan senilai.

Berdasarkan hasil tes akhir tindakan siklus II, diperoleh informasi bahwa dari 27 siswa yang mengikuti tes terdapat 20 siswa yang tuntas dan 7 siswa lainnya tidak tuntas karena belum mencapai kriteria ketuntasan belajar. Adapun persentase ketuntasan belajar klasikal yang dicapai pada siklus II sebesar $74.07 \%$.

Aspek yang diamati meliputi: (1) Mengucapkan salam, menyuruh siswa berdoa, mengecek kehadiran siswa, serta menyiapkan siswa untuk belajar. (2) Menyampaikan informasi tentang subpokok bahasan yang akan dipelajari, serta menyampaikan tujuan pembelajaran dan hasil belajar yang diharapkan dapat dicapai siswa serta memotivasi siswa agar tumbuh keinginan siswa untuk mempelajari materi perbandingan dengan mengaitkan konsep yang hendak dipelajari dengan kehidupan sehari-hari dan kaitannya dengan materi yang dipelajari. (3) Melakukan apersepsi untuk mengecek pengetahuan prasyarat siswa tentang mengkonversi satuan dan penyederhanaan pecahan melalui pertanyaan. (4) Menyajikan materi perbandingan senilai dengan mengaitkan konsep tersebut dengan realita kehidupan sehari-hari (5) Menyajikan materi perbandingan senilai dengan pemberian contoh atau model dari realita kehidupan sehari-hari (6) Guru memberikan kesempatan kepada siswa untuk bertanya tentang hal yang belum dipahami (7) Mengelomopokkan siswa secara heterogen brdasarkan tes awal. (8) Menyampaikan hal-hal yang akan siswa lakukan dalam kelompok masing-masing. (9) Memberikan LKPD kepada masing-masing kelompok (10) Memonitoring kerja siswa dan menjelaskan kepada siswa agar dapat bekerja sama dengan teman kelompoknya serta memberikan kesempatan kepada siswa untuk menanyakan hal-hal yang belum dipahami dalam LKPD serta memberikan bantuan seperlunya yang sifatnya mengarahkan (11) Meminta siswa membuat kesimpulan mengenai LKPD yang telah dikerjakan oleh siswa. (12) Meminta siswa mempresentasikan hasil diskusinya dan kelompok lain menanggapi atau mengajukan pertanyaan (13) Guru memberikan penghargaan berupa pujian kepada kelompok yang terbaik (14) Memberikan tes akhir tindakan (15) Memberikan Tes Akhir Tindakan Meminta siswa membuat kesimpulan dari penerapan komponen Contextual Teaching and Learning yang dikaitkan dalam kehidupan sehari-hari (16) Memberikan refleksi terhadap kegiatan pembelajaran yang telah dilakukan (17) Menutup Pembelajaran.

Hasil observasi pengamat terhadap aktivitas guru yaitu: aspek nomor 2, 4, 5, 6, 7, 8, 10, 11, 12, 13, 15 dan 16 memperoleh nilai 3; aspek nomor 1, 3, 9, 14 dan 17 memperoleh nilai 4. Dan hasil observasi aktivitas guru pada siklus I pada kategori baik. Hasil observasi 
pengamat terhadap aktivitas guru yaitu: aspek nomor 6, 10, 12 dan 15 memperoleh nilai 3; aspek nomor $1,2,3,4,5,7,8,9,11,13,14,16$ dan 17 memperoleh nilai 4. Dan hasil observasi aktivitas guru pada siklus II pada kategori sangat baik.

Aspek yang diamati meliputi: (1) Menjawab salam dan berdoa bersama serta siswa menyampaikan siswa yang tidak hadir. (2) Memperhatikan penjelasan guru pada saat menyampaikan, subpokok, tujuan pembelajaran, hasil yang ingin dicapai dan motivasi dari guru (3) Menjawab pertanyaan dari guru (4) Memperhatikan, memahami dan mendengarkan penjelasan guru dengan seksama, serta mengikuti kegiatan pembelajaran dengan antusias, termotivasi dan berusaha berpartispasi aktif untuk menjadi model dalam pembelajaran (5) Memperhatikan, memahami dan mendengarkan penjelasan guru dengan seksama.(6) Mengajukan pertanyaan jika ada yang dianggap belum dimengerti (7) Siswa Bergabung dengan kelompoknya masing-masing (8) Mendengarkan penjelasan guru (9) Menerima LKPD dari guru (10) Bekerjasama dengan teman kelompoknya dan bertanya jika ada yang belum dipahami dalam menyelesaikan LKPD (11) Membuat kesimpulan dari hasil yang diperoleh siswa dalam menyelesaikan LKPD (12) Perwakilan setiap kelompok maju kedepan untuk mempresentasikan hasil kerja kelompoknya (13) Menerima penghargaan berupa pujian dari guru sebagai kelompok terbaik (14) Mengerjakan tes yang diberikan (15) Menyimpulkan materi yang baru saja dipelajari (16) Mendengarkan penjelasan guru sebagai bahan refleksi siswa (17) Berdoa bersama dan menjawab salam

Hasil observasi pengamat terhadap aktivitas siswa yaitu: aspek nomor 4, 6, 10 dan 12 memperoleh nilai 2; aspek nomor 1, 2, 3, 5, 7, 8, 11, 13, 15 dan 16 memperoleh nilai 3; aspek nomor 9, 14 dan 17 memperoleh nilai 4. Dan hasil observasi aktivitas siswa pada siklus I pada kategori baik. Hasil observasi pengamat terhadap aktivitas siswa yaitu: aspek nomor 2, 3, 4, 5, 6, 10, 11, 12, 15 dan 16 memperoleh nilai 3; aspek nomor 1, 7, 8, 9, 13, 14 dan 17 memperoleh nilai 4. Dan hasil observasi aktivitas siswa pada siklus II pada kategori sangat baik.

\section{PEMBAHASAN}

Penelitian ini merupakan penelitian tindakan Kelas (PTK) yang bertujuan untuk meningkatkan hasil belajar pada materi perbandingan khususnya materi perbandingan senilai dan perbandingan berbalik nilai di kelas VII SMP Negeri 22 Palu. Penelitian ini dilaksanakan dalam dua siklus. Setiap siklusnya terdiri dari 4 komponen yang meliputi : (1) Perencanaan, (2) pelaksanaan tindakan, (3) Observasi, (4) Refleksi. Hal ini sesuai dengan desain penelitian yang mengacu pada model Kemmis dan Mc. Taggart yang terdiri dari 4 komponen yaitu petencanaan, tindakan dan pengamatan, serta refleksi (Arikunto, 2007).

Sebelum pelaksanaan tindakan, peneliti yang bertindak sebagai guru terlebih dahulu memberikan tes awal kepada siswa untuk mengetahui kemampuan awal siswa pada materi prasyarat. Hasil tes awal digunakan sebagai pedoman dalam penentuan informan dalam penelitian. Hal ini sesuai dengan pendapat Paloloang (2014:73) bahwa pemberian tes awal sebelum pelaksanaan tindakan bertujuan untuk mengetahui kemampuan siswa pada materi prasyarat dan sebagai pedoman dalam penentuan informan.

Pada pelaksanaan tindakan, peneliti menerapkan pendekatan Contextual Teaching and Learning (CTL) untuk meningkatkan hasil belajar. Pembelajaran materi perbandingan senilai dan berbalik nilai dengan pendekatan CTL merupakan suatu strategi pembelajaran yang mengaitkan materi perbandingan senilai dan berbalik nilai dengan kehidupan nyata yang dimiliki siswa. Siswa akan mengaitkan pengetahuan tang sudah dimilikinya dalam kehidupan sehari-hari sehingga siswa lebih cepat mengerti dan pembelajaran menjadi lebih bermakna. 
Hal ini sejalan dengan pendapat Suprijono (2010:79) pembelajaran kontekstual merupakan konsep yang membantu guru mebgaitkan antara materi yang diajarkannya dengan situasi dunia nyata siswa dan mendorong siswa membuat hubungan antara pengetahuan yang dimilikinya dengan penerapannya dalam kehidupan mereka sebagai anggota keluarga dan masyarakat.

Pada kegiatan awal peneliti membuka pelajaran dengan mengucapkan salam, mengajak siswa berdoa, mengecek kehadiran siswa. Selanjutnya peneliti menyiapkan siswa untuk belajar, hal ini bertujuan agar siswa menjadi lebih siap mengikut pembelajaran karena kesiapan siswa dalam mengikuti pembelajaran sangat penting dalam menunjang keberhasilan suatu pembelajaran. Hal ini sejalan dengan pendapat Soejanto dalam Hasanah (2017) yang mengemukakan bahwa kesiapan diri siswa sangat penting untuk meraih keberhasilan dalam kegiatan belajar. Selanjutnya peneliti menyampaikan judul materi dan tujuan pembelajaran yang hendak dicapai. Peneliti juga memberikan motivasi kepada siswa yang bertujuan untuk memberikan semangat kepada siswa dalam mengikuti pembelajaran. Motivasi yang diberikan berupa manfaat yang akan diperoleh siswa setelah mempelajari meteri perbandingan senilai dan berbalik nilai. Sesuai dengan pendapat Djamarah dalam Hasanah (2017)yang mengemukakan bahwa motivasi belajar itu diperlukan karena seseorang yang tidak memiliki motivasi tak akan mungkin melakukan aktivitas belajar. Selanjutnya peneliti memberikan apersepsi kepada siswa. Sesuai dengan pendapat Ningsih dalam Hasanah (2017) yang mengemukakan bahwa kegiatan pemberian apersepsi adalah kegiatan yang dilakukan oleh guru untuk menciptakan suasana siap mental dan menimbulkan perhatian siswa agar terpusat pada hal-hal yang akan dipelajari. Adapun apersepsi yang diberikan pada siklus I sebelum mempelajari matei perbandingan senilai yaitu menanyakan tentang materi perbandingan. Sedangkan apersepsi yang dilakukan pada siklus II yaitu dengan memberikan materi perbandingan senilai sebelum memepelajari materi perbandingan berbalik nilai. Kegiatan yang dilakukan pada komponen CTL konstruktivisme yaitu peneliti menyajikan materi perbandingan senilai dengan cara menanyakan uang jajan 2 orang siswa kemudian membandingkannya sehingga siswa mampu membangun pengetuannya sendiri melalui proses pengamatan dan pengalaman. Sesuai dengan pendapat Pieaget dalam Sanjaya (2005) yang menyatakan bahwa pengetahuan itu bukan hanya dari objek semata, akan tetapi juga dari kemampuan individu sebagai subjek yang menangkap setiap objek yang diamatinya. Peneliti memberikan stimulus kepada siswa mengenai benda-benda yang berkaitan dengan materi perbandingan senilai. Setelah memberikan stimulus, peneliti menyajikan masalah dalam kehidupan dalam kehidupan sehari-hari yang berkaitan dengan materi perbandinagn senilai. Sedangkan pada siklus II peneliti menyajikan materi perbandingan berbalik nilai dengan cara menanyakan perbandingan kecepatan motor siswa dan lamanya sampai disekolah pada saat mengendarai motor.

Kegiatan yang dilakukan pada komponen CTL masyarakat belajar untuk pertemuan setiap siklus yaitu peneliti mengelompokkan siswa kedalam 6 kelompok belajar yang heterogen agar siswa saling bekerja sama, saling mengajarkan antar siswa. Sesuai dengan penadapat Muslich (2009) yang menyatakan konsep masyarakat belajar dalam CTL masyarakat agar hasil pemebelajaran diperoleh melalui kerja sama dengan orang lain. Selanjutnya, peneliti memberikan LKPD kepada masing-masing kelompok.

Kegiatan yang dilakukan pada komponen CTL Inkuiri yaitu peneliti mengarahkan siswa untuk menemukan pengertian perbandingan senilai dan berbalik nilai,rumus dan menyelesaikannya. Sesuai dengan pendapat Rianto dalam Hasanah (2017) yang menyatakan bahwa melalui upaya menemukan akan memberikan penegasan bahwa pengetahuan dan keterampilan serta kemampuan-kemampuan lain yang diperlukan bukan merupakan hasil dari mengingat seperangkat faktra-fakta, tetapi merupakan hasil dari menemukan sendiri. 
Kegiatan yang dilakukan pada komponen CTL penilaian autentik pada 2 siklus yaitu peneliti memonitoring setiap kelompok, menjelaskan kepada siswa agar dapat bekerja sma dengan kelompoknya serta membimbing siswa jika belum memahami. Sesuai dengan pendapat Sanjaya (2005) yang menyatakan bahwa penilaian dilakukan secara terus menerus selama kegiatan pembelajaran berlangsung.

Kegiatan yang dilakukan pada komponen CTL pemodelan pada 2 siklus yaitu peneliti meminta perwakilan setiap kelompok untuk mempresentasikan hasil kerja kelompoknya. Sesuai dengan pendapat Muslich (2009) yang mengemukakan bahwa cara pembelajaran seperti ini, akan lebih cepat dipahami siswa daripada hanya bercerita dan memberikan penjelasan kepada siswa tanpa ditunjukkan model atau contohnya. Selanjutnya meminta kelompok lain untuk menanggapi. Sesuai dengan pendapat Rahmawati (2013) yang mengemukakan bahwa dalam pembelajaran matematika siswa perlu dibiasakan untuk memberikan argumen atau setiap jawabannya serta memberikan tangganpan atas jawaban yang diberikan orang lain, sehingga apa yang dipelajari menjadi lebih bermakna.

Kegiatan yang dilakukan pada komponen CTL bertanya yaitu peneliti melakukan tanya jawab terhadap siswa untuk mengetahui pengetahuan/pemahaman yang telah didapatkan oleh siswa dalam proses pembelajaran. Sesuai dengan pendapat Rianto dalam Hasanah (2017) bahwa bertanya merupakan strategi utama pembelajaran yang berbasis CTL. Bertanya dipandang guru sebagai pendorong, membimbing, dan menilai kemampuan berpikir siswa.

Kegiatann akhir setiap siklus yaitu peneliti membimbing siswa membuat kesimpulan dari materi perbandingan senilai dan berbalik nilai. Sesuai dengan pendapat Purnomo dalam Hasanah (2017) bahwa guru membimbing siswa untuk menarik kesimpulan-kesimpulan yang sesuai dengan temuan siswa. Selanjutnya, peneliti memberikan refleksi terhadap kegiatan pembelajaran.

Setelah kegiatan pembelajaran siklus I berakhir, peneliti bersama observer melakukan refleksi terhadap sluruh kegiatan pembelajaran yang telah dilakukan. Refleksi ini bertujuan untuk mengetahui kekurangan-kekurangan yang terjadi pada saat pelaksanaan proses pembelajaran dengan pendekatan CTL pada siklus I untuk dijadikan rekomendasi kegiatan perbaikan pada saat proses pembelajaran dengan pendekatan CTL di siklus II.

Berdasarkan hasil dan pembahasan di atas menunjukkan bahwa aktivitas guru dan aktivitas siswa dalam pembelajaran mengalami peningkatan dan indikator keberhasilan tindakan telah tercapai. Hal ini menunjukkan adanya peningkatan hasil belajar siswa kelas VII SMP Negeri 22 Palu pada materi limit fungsi aljabardengan menerapkan model pembelajaran langsung. Hasil tes akhir tindakan diperoleh siswa yang mengalami ketuntasan sebanyak 16 siswa dengan persentase ketuntasan $59.25 \%$ di siklus I dan 20 siswa mengalami ketuntasan dengan persentase ketuntasan $74.07 \%$ pada siklus II. Artinya bahwa terdapat peningkatan mulai dari hasil tes awal.Hal ini mengindikasikan bahwa indikator keberhasilan tindakan telah berhasil.

\section{KESIMPULAN}

Berdasarkan hasil penelitian dan pembahasan disimpulkan bahwa Pembelajaran dengan menerapkan Pendekatan Contextual Teaching and Learning (CTL) dapat meningkatkan hasil belajar siswa pada materi perbandingan khususnya perbandingan senilai dan perbandingan berbalik nilai siswa kelas VII SMP Negeri 22 Palu dengan mengikuti langkah-langkah yaitu : peneliti melakukan absensi, menyampaikan tujuan pembelajaran dan memotivasi siswa serta memberikan apersepsi mengenai materi yang akan dipelajari, selanjutnya peneliti mendampingi siswa mengkonstruksi pengetahuan mereka melalui interaksi mereka dengan 
objek, fenomena, pengalama, dan lingkungan mereka serta guru memberikan stimulus agar siswa mengungkapkan apa yang ada didalam pikiran siswa. Pada kegiatan ini komponen CTL yang diterapkan adalah Konstruktivisme, kemudian peneliti menyajikan suatu masalah yang ada dikehidupan sehari-hari yang berkaitan dengan materi yang diajarkan dan guru mengarahkan siswa untuk dapat menemukan pemecahan masalah yang diberikan. Pada kegiatan ini menemukan pemecahan masalah yang diberikan. Pada kegiatan ini komponen CTL yang diterapkan adalah Menemukan, setelah itu peneliti mengorganisasikan siswa kedalam kelompok-kelompok belajar yang heterogen dan guru membagikan LKPD serta model yang digunakan sebagai contoh pembelajaran. Pada kegiatan ini komponen CTL yang diterapkan adalah Masyarakat Belajar, selanjutnya peneliti meminta perwakilan kelompok untuk mempresentasikan hasil kerja kelompoknya. Pada kegiatan ini komponen CTL yang diterapkan adalah Pemodelan. kemudian peneliti menggali pemahaman siswa dengan cara tanya jawab untuk mengetahui tingkat pemahaman siswa mengenai materi yang dipelajari. Pada kegiatan ini komponen CTL yang diterapkan adalah Bertanya, selanjutnya peneliti membimbing siswa untuk membuat kesimpulan sesuai dengan tujuan pembelajaran yang telah ditentukan dan guru memberikan refleksi terhadap kegiatan pembelajaran yang telah dilakukan. Pada kegiatan ini komponen CTL yang diterapkan adalah Refleksi, langkah selanjutnya peneliti memonitoring kerja siswa, menjelaskan kepada siswa agar dapat bekerja sama, serta membimbing siswa jika ada yang belum dipahami dan guru mengumpulkan LKPD hasil diskusi siswa dalam kelompok. Pada kegiatan ini komponen CTL yang diterapkan adalah Penilaian Autentik, langkah terakhir peneliti memberikan penghargaan kepada kelompok terbaik berupa nilai tambahan.

Ketuntasan belajar klasikal pada siklus I mencapai $59.25 \%$ dan pada siklus II ketuntasan belajar klasikal mencapai 74.07\% . Sedangkan, hasil observasi guru dan siswa pada siklus I berada pada kategori baik dan pada siklus II hasil observasi gurudan berada pada kategori sangat baik.

\section{SARAN}

Berdasarkan kesimpulan, peneliti dapat memberikan beberapa saran yaitu pembelajaran dengan menerapkan pendekatan CTL dapat dijadikan sebagai alternatif guru dalam meningkatkan hasil belajar siswa pada materi perbandingan serta pada materi lainnya. Bagi calon peneliti berikutnya agar dapat menerapkan pendekatan CTL paada materi lain, untuk mengetahui efektivitas model ini dalam rangka peningkatan hasil belajar siswa.

\section{DAFTAR PUSTAKA}

Arikunto, S. (2007). Penelitian Tindakan Kelas. Jakarta: Bumi Aksara.

Depdiknas. (2006). Kurikulum Tingkat Satuan Pendidikan (KTSP) 2006 Mata Pelajaran Matematika. Jakarta: Depdiknas

Hadjar, I. (2014). Perbandingan Kemampuan Siswa Dalam Pemecahan Masalah Segiempat Dengan Contextual Teaching And Learning (CTL) dan Pembelajaran Konvensional Di Kelas VII SMPN 7 Palu. Dalam Jurnal Pendidikan Matematika. Vol.3 (1), 9 halaman. [Online] Tersedia : http://jurnal.untad.ac.id/jurnal/ index. php/ AKSIOMA /article/ view/ 7969/6305.pdf. [29 Januari 2018]

Harmawati. (2016). Penerapan Contextual Teaching and Learning untuk Meningkatkan Hasil Belajar Siswa dalam Menyelesaikan Soal Cerita Penjumlahan dan Pengurangan Pecahan di Kelas VII SMP Negeri Satu Atap UK Layana Indah. Dalam Jurnal Pendidikan 
Matematika. Vol.3(4), 13 halaman. [Online] Tersedia : http://jurnal.untad.ac.id/jurnal/ index.php/JEPMT/article/viewFile/7227/5816.pdf. [11 Mei 2017].

Hasanah, U. (2017). Penerapan Pendekatan Contextual Teaching and Learning untuk Meningkatkan Hasil Belajar Siswa Pada Materi Luas Permukaan dan Volume Balok Siswa Kelas VIII A2 SMP Negeri 14 Palu. Skripsi sarjana pada FKIP UNTAD Palu : tidak diterbitkan.

Jurdin. (2015). Penerapan Pembelajaran Kontekstual (CTL) untuk Meningkatkan Hasil Belajar Matematika Pada Materi Pengukuran Waktu dan Sudut dalam Notasi 12 Jam Terhadap Siswa Kelas VB SD Karuna DIPA Palu. Skripsi sarjana pada FKIP UNTAD Palu : tidak diterbitkan.

Muslich, M. (2009). KTSP Pembelajaran Berbasis Komponen dan Kontekstual. Jakarta: Bumi Aksara.

Paloloang, F. B. (2014). Penerapan Model Problem Based Learning untuk Meningkatkan Hasil Belajar Siswa pada Materi Panjang Garis Singgung Persekutuan Dua Lingkaran di Kelas VIII SMP Negeri 19 Palu. Jurnal Elektronik Pendidikan Matematika Tadulako [Online]. Vol.2 (1), $11 \mathrm{hlm}$. Tersedia : http://jurnal.untad.ac.id/jurnal/index.php/JEPMT/ article/view/3232/2287 [04 Agustus 2017]

Rahmawati, F. (2013). Pengaruh Pendekatan Pendidikan Realistik Matematika dalam Meningkatkan Kemampuan Komunikais Matematis Siswa Sekolah Dasar. Jurnal FMIPA Unila. Vol. I, No.1, 14 halaman. [Online]. Tersedia : http://journal.fmipa. Unila.ac.id.index.php/semirata/article/view/882/701. [11 September 2018]

Sanjaya,W. (2005). Pembelajaran dalam Implementasi Kurikulum Berbasis Kompetensi. Bandung : Kencana Prenada Media Grup.

Sugiyono. (2014). Metode Penelitian Kuantitatif, Kualitatif, dan R\&D. Bandung: Alfabeta.

Suprijono, A. (2009). Cooperative Learning Teori dan Aplikasi PAIKEM. Surabaya: Pustaka Belajar. 